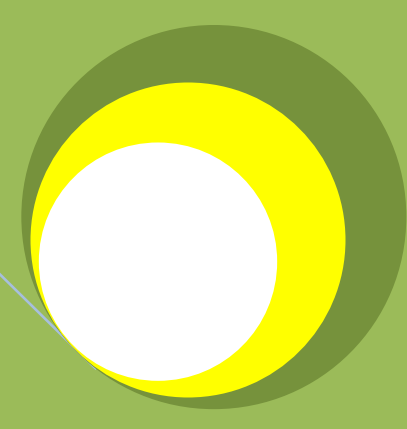

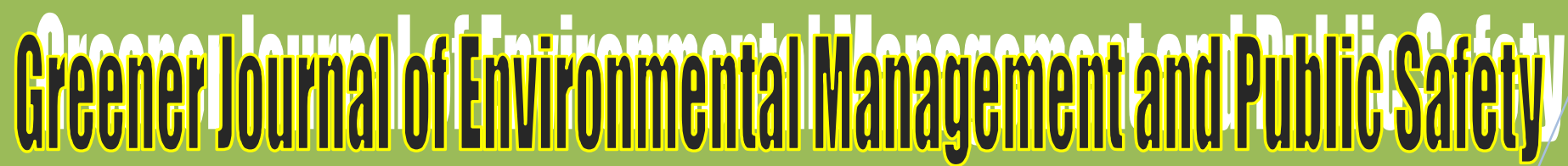
ISSN: 2354-2276

An Empirical Analysis of the Relationship between Plantation Development and Urbanization in the Mungo Corridor of Cameroon By

Cletus Forba Fru Jude Ndzifon Kimengsi 
Research Article (DOI: http://doi.org/10.15580/GJEMPS.2015.1.042914209)

\title{
An Empirical Analysis of the Relationship between Plantation Development and Urbanization in the Mungo Corridor of Cameroon
}

\section{Cletus Forba Fru ${ }^{1 *}$ and Jude Ndzifon Kimengsi ${ }^{2}$}

\author{
${ }^{1}$ Department of Geography, University of Buea, P.O. Box 63, Buea Cameroon. \\ ${ }^{2}$ Department of Geography and Environmental Studies, Catholic University of Cameroon (CATUC), P.O. Box 753 \\ Bamenda Cameroon. \\ 2Email: ukjubypro2@yahoo.com
}

${ }^{*}$ Corresponding Author's Email: forbacle@yahoo.com

\begin{abstract}
The establishment of agro-plantations which is a colonial legacy is an important contributor to urban development in Tropical Africa. This paper examines the process of agro-industrial plantation development and consequent urbanization in the Mungo Corridor - an agricultural curnocupia of the Littoral Region of Cameroon. With the aid of field surveys and the distribution of 100 questionnaires using the systematic sampling technique which were complemented by secondary sources, the study employed the correlational analysis to establish a relationship between the establishment of plantations and urbanization in the Mungo Corridor. In establishing a nexus between the spatial distribution of plantations and the process of urbanization in the Mungo Corridor, the empirical results showed that most of the indicators of agro-industrial development and urbanization have linear relationships at $1 \%, 5 \%$ and $10 \%$ levels of significance. Furthermore, this paper argues that although other factors might have contributed to the urbanisation process of the Mungo Corridor, the role of agro-industrial plantation development stand out clear. As such a process is noted to have precipitated urban development challenges, the study recommends, among others, that the Delegation of Urban Development, in collaboration with the councils should embark on measures aimed at ensuring urban renewal by designing a comprehensive programme for planning and development of new layouts in the area. In addition, camps should be improved upon by rehabilitation and refurbishment while a proper waste treatment method should be adopted by the plantation establishments to mitigate the attendant effects of pollution that the populations already decry. Finally, it seems logical and equitable that the plantation authorities should cede or surrender some land to the local population to provide them with space for food cropping and housing construction.
\end{abstract}

Keywords: plantation development, urbanisation, Mungo Corridor.

\section{INTRODUCTION}

One of the legacies left by the Europeans in their colonies has mainly been the establishment of agro-industrial plantations. These plantations, it should be noted, were intended to provide raw materials for their industries (Kimengsi, 2008). The introduction of plantations in an area enhances the process of urbanisation which is characterised by the growth of a number of developmental activities.

Urbanization which denotes a shift from a rural to an urban society involving an increase in the number of people in urban areas and the consequent expansion of these areas is the outcome of social, economic and political developments that lead to population concentration and the growth of large cities, changes in land use and transformation from rural to metropolitan pattern of organization and governance (Nsiah-Gyabaah, 2008). One significant feature of the urbanization process in Africa is that, unlike Asia and Europe, much of the growth is taking place in the absence of significant industrial expansion. An offshoot of urbanization is the outward expansion of the built-up area and the conversion of prime agricultural lands into residential and industrial uses.

Urbanisation results from natural increase in population and the influx of migrants into a particular region. However, and most recently, rural exodus has largely contributed to the rapid urbanisation which is experienced in many urban areas of the world. Across the Developing Countries, the development of agro-industrial plantations has been a precursor for urban development and urbanization. This is particularly the case with Brazil and Nigeria after 
independence. In these countries, agro-industrial development contributed to a rise of GDP of up to $50 \%$ which was followed by massive urbanization (Ogen, 2007).

In the Mungo Corridor of Cameroon, the same scenario obtains. In these areas, the development of agroindustries has been a driving force behind the urbanization process. Due to a number of physical (climate, relief, geology and soils) and human conditions (population, transport connectivity and a ready market) which are favourable for the establishment of plantations, these areas have witnessed the establishment of huge plantations of varied cahs srop types. The cultivation of large hectares of land by corporations such as the Plantation du Haut Penja (PHP), in the Mungo Division has been a spring board to the urbanization process in these regions through the establishment of camps to house plantation labourers. The creation of such camps has catalyzed the urbanization process.

\section{PROBLEM STATEMENT}

There is no gainsaying the fact that the establishment of agro-plantations which is a legacy of the colonial era in most parts of Tropical Africa has been the brain behind major societal transformation, particularly through the process of urbanization. This goes to buttress the intricate relationship that exists between agro-induatrial plantation development and urbanization. The inception of agro-industrial development in the Mungo Corridor has been a major contributing factor towards the rapid urban growth witnessed in the study area. A clear example is the fact that between Loum and Nkapa, at least six main settlements are seen which are continuously increasing in their population and areal extent. The presence of these agro-industrial establishments acts as a "population trap", pulling immigrants from other parts of the country to take advantage of the opportunities available in these regions which accounts for the growth of several settlements (Loum, Penja-Njombe, Mbanga, Nkapa and Souza). Urbanisation has led to an increase in the demand for space and other urban functions as the settlements expand. Population growth caused by rural exodus, coupled with poor spatial planning and the increase of private housing has contributed to the rapid growth of these urban areas. Unfortunately, this rapid growth is characterized by an effete (weak) urbanization, with little or no provision for housing infrastructure.This paper argues that although other factors might have contributed to the urbanisation process of the Mungo Corridor, the role of agro-industrial plantation development stand out clear.

\section{THE STUDY AREA}

The study area is in the Littoral Region of the Republic of Cameroon (Figures 1\&2). Geographically, it is located between latitudes $4^{\circ} 10^{\prime}-4^{\circ} 50^{\prime}$ North of the Equator, and longitudes 9 ${ }^{\circ} 20^{\prime}-9^{\circ} 50^{\prime} \mathrm{E}$ of the Greenwich meridian.

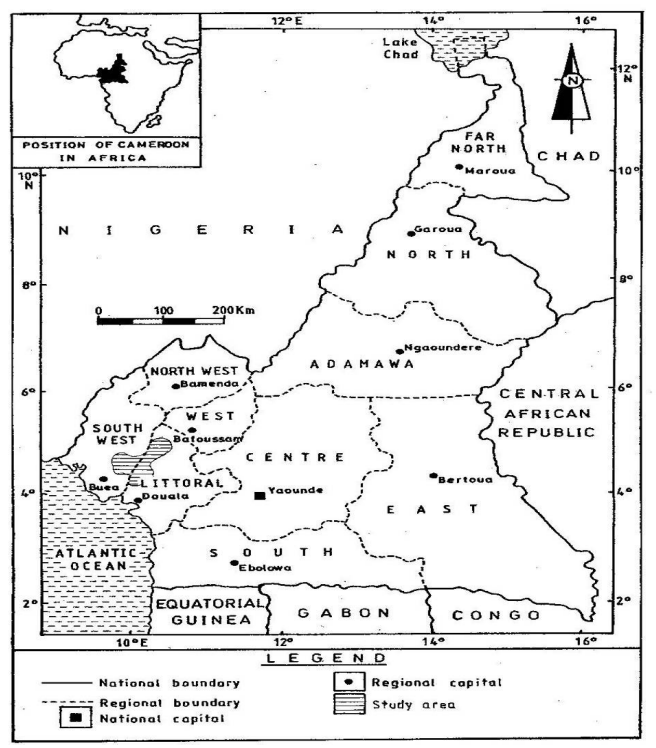

Figure 1: Location of the Study Area in Cameroon

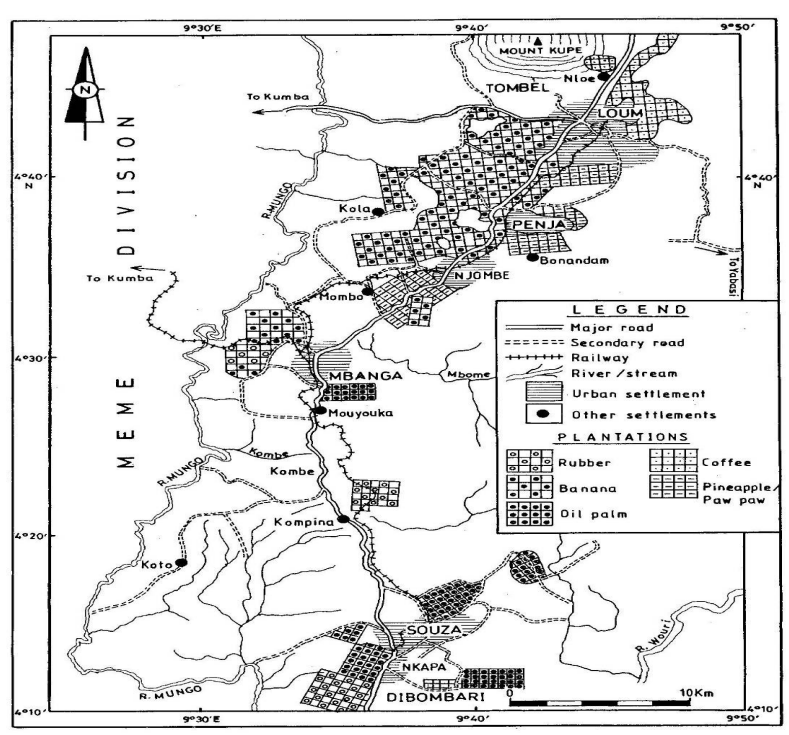

Figure 2: Spatial Distribution of Plantations in the Mungo Corridor 
The major settlements in the area include Loum, Penja, Njombe, Mbanga, Nkapa and Souza. The study area is characterized by a very dense population that are scattered in various settlements. Mbanga town as of 2009, has a population of about 140,000 and covers a surface area of about $544 \mathrm{~km}^{2}$ (population density of 257 inhabitants $/ \mathrm{km}^{2}$ ) while Njombe and Penja are populated by about 50,800 inhabitants with a surface area of about $260 \mathrm{~km}^{2}(195$ inhabitants $/ \mathrm{km}^{2}$ ) (Ako et al., 2010). The populations of these towns have witnessed rapid increase between 1987 and 2006. For instance, the population of Njombe and Penja increased from 33,000 to 50,000 while that of Loum went from 67,000 to 110,000 inhabitants (GTZ, 2006). About $40 \%$ of the population of the study area is resident in camps that are located within some of the agro industrial plantations that characterise the study area.

The methodology focused on field surveys and the distribution of 100 questionnaires using the systematic sampling technique which were complemented by secondary sources. Sampling targeted the plantation workers and the inhabitants of the Mungo Corridor. The study employed the correlational analysis with the aid of the Stata 11.1 Statistical Package to establish a relationship between the establishment of plantations and urbanization in the Mungo Corridor. The empirical results establishing relationships between the indicators of plantation development and urbanization were validated at $1 \%, 5 \%$ and $10 \%$ levels of significance.

\section{LITERATURE REVIEW}

The changing nature of some Cameroonian settlements from rural to urban settlements and the rate of increase in the nature of urban functions have been rapid since 1972 when the United Republic of Cameron came to existence (Fombe and Balgah, 2010). The pace of urbanization in Cameroon, just like every other West African nations, have been very rapid. In 1976, the rate of urbanization was $28.5 \%$ and this figure grew $40.4 \%$ in 1988 (Tarkang, 1988, cited in Fombe and Balgah, 2010) and the current figure reveal an increase of over $5 \%$. It is projected that with the current growth rate, over $50 \%$ of the country's population will be urbanized by 2015 . Perhaps, a major factor behind this trend is the role of plantations in spurring the urbanization process as observed in the Mungo Corridor.

Scholars in the field of plantation studies have provided a balanced and seemingly objective opinion about the factors, relevance and flipsides of plantation establishment and urbanization. To Ako et al. (2010), the development of plantation agriculture and the fertility of the soils in the Banana plain (Mungo Corridor) have created a pole of attraction for labourers from Cameroon and beyond. The towns of Mbanga, Njombe, Penja and Loum have witnessed significant transformations because of plantation agriculture.

Fossung (2001) views the Cameroon Development Corporation (CDC) - the second largest employer after the government of Cameroon as a major actor in the regional transformation of Cameroon. His argument centres on the fact that CDC plantations have ushered in a lot of socio-economic and infrastructural benefits within their areas of operation. Such transformations cannot be dissociated from urbanization especially as plantations act as a "population trap" (Kimengsi, 2009).

In a related dimension, Narayanan and Hanjagi (2009) expressed the view that agricultural plantations are major victims of urbanization and the resultant transformations are classified under three categories, they include, the built, fallow and no-change transformations. No change is associated with the category that was resistant to urbanization and has not changed over years; fallow shows a serious threat and uncertainty for conversion or nonconversion but, is vulnerable under the threat of sprawl. The next category being built is that agricultural plantations are victimized for urban growth. They cautioned that such a transformation is irrevocable and calls for serious attention of urban planners. This idea tallies very much with the observed urban transformations witnessed in the Mungo Corridor; thanks to the development of extensive plantations. However, the development of such urban transformations do not have similar outcrop of the built up area since they occur at different paces.

In explaining the flipsides of plantation-driven urbanization, Kimengsi (2009) holds that contrary to the economic euphoria brought about by the establishment of Pamol Plantations as it contributes to socio-economic and infrastructural development in the area of operation, there is a need to investigate the land use conflict emanating from urban development which is largely a resultant effect of agro-industrial establishment. Capa and Stycos (1974) expressed the view that plantation systems are characterized by an extreme concentration of the share of total wealth and income in the hands of a relatively small upper stratum and the emergence of a rural wage labour force. The plantations have caused a majority of the adjacent populations to become impoverished, increasingly propertyless, and largely denied the benefits of rising incomes and expanding educational opportunities. They therefore live in abject poverty (Karush, 1978). The paradox of plantation agriculture is that as it leads to the concentration of people in an area and consequent urbanisation, it also robs the adjacent natives of their land (Nasreen et al., 2006; Kimengsi, 2008). The long term effect is always landlessness and the upsurge of a number of land use conflicts. 


\section{RESULTS}

The results are presented basically under two key subheadings; they include the Evolution of Plantations in the Mungo Corridor and Agro-Industrial Development and Urbanization.

\section{Evolution of Plantations in the Mungo Corridor}

Between 1960 and 2010 the major plantation crops have witnessed some significant evolution over the years in terms of their total land area exploited. A more than 35\% increase in the size of their plantations was registered for all plantation crops (Table 1). The increase therefore encouraged labourers to migrate into the plantations which led to increase in population to fuel the urbanisation process of the town.

Table 1: Evolution of Major Plantation Crops in the Mungo Corridor

\begin{tabular}{|c|c|c|c|c|c|}
\hline \multicolumn{6}{|c|}{ Youm } \\
\hline Crops (ha) & \multicolumn{7}{|c|}{ \% change in ha } \\
\hline & $\mathbf{1 9 6 0}$ & $\mathbf{1 9 8 0}$ & $\mathbf{2 0 0 0}$ & $\mathbf{2 0 1 0}$ & \\
\hline Banana & 500 & 700 & 810 & 940 & 47 \\
\hline Pineapple & 65 & 90 & 150 & 185 & 65 \\
\hline Oil palm & 30 & 35 & 45 & 50 & 40 \\
\hline Cocoa & 10 & 18 & 35 & 40 & 75 \\
\hline Pawpaw & 40 & 58 & 86 & 100 & 60 \\
\hline Banana & 350 & 800 & 1,500 & 2,000 & 83 \\
\hline Pineapple & 30 & 55 & 82 & 100 & 70 \\
\hline Oil palm & 320 & 650 & 890 & 1,100 & 71 \\
\hline Cocoa & 36 & 65 & 76 & 90 & 60 \\
\hline Pawpaw & 23 & 40 & 49 & 60 & 62 \\
\hline Banana & 1,400 & 1,850 & 2,400 & 2,820 & 50 \\
\hline Pineapple & 120 & 250 & 400 & 555 & 78 \\
\hline Oil palm & 21 & 44 & 58 & 70 & 70 \\
\hline Cocoa & 10 & 20 & 25 & 30 & 67 \\
\hline Pawpaw & 60 & 86 & 110 & 150 & 60 \\
\hline Rubber & 40,000 & 52,150 & 57,000 & 63,180 & 37 \\
\hline Oil palm & 1,200 & 26,000 & 40,000 & 4,720 & 75 \\
\hline Cocoa & 25 & 58 & 77 & 100 & 75 \\
\hline Source: Coman
\end{tabular}

Source: Compiled from PHP, SPM, SOCAPALM, MINADER Reports, 2011

\section{Agro-Industrial Development and Urbanization}

A nexus was observed between the growth of agro-plnatations and urbanization; the plantation areas, almost invariably develop their living quarters close to the farms to ease the movement of labour into these plantations. In a related dimension, the mean values for the indicators of agro-industrial development in the Mungo Corridor showed that the growth of smallholder schemes registered $80 \%$ and is thus viewed as a crucial indicator (Figure 3). This implies that the presence of these major agro plantations spurred the development of smallholder schemes in the area. This is immediately followed by the growth of linked industries (71\%) which supply raw material to or uses up the outputs of the existing agro-industries and helps to stimulate the growth of this sector. On the whole, all the indicators were significant, registering above $60 \%$.

Urbanisation in the Mungo Corridor is phenomenal as indicated by the mean values observed (Figure 4). Inmigration occupied a very significant position, having $89 \%$. This is explianed by the fact that, the presence of plantations attracts migrants from other parts of the country, especially from the West and North West Regions to move into the area and work in the plantations. Closely followed, is population increase which is linked to natural increase and inmigration. On the whole, all the indicators of urbanisation registered mean values above $50 \%$. 


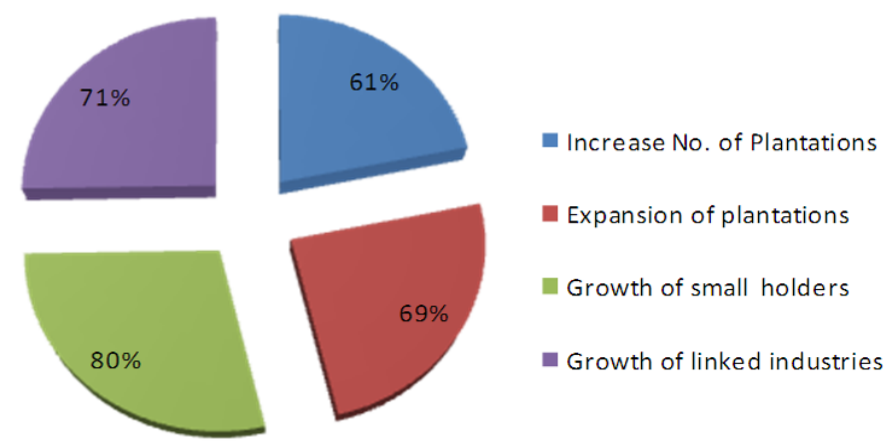

Figure 3: Indicators of Agro-Industrial Development in the Mungo Corridor (Source: Field work, 2013)

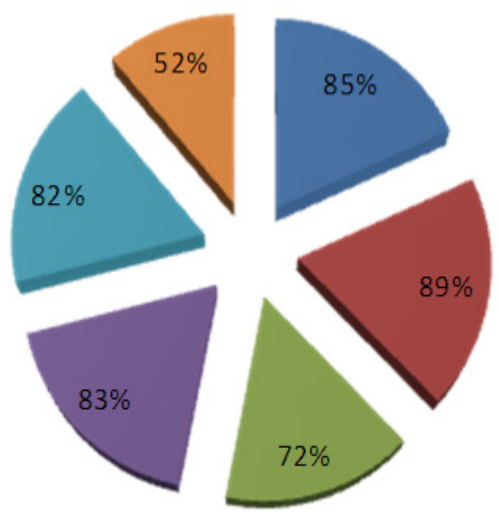

- Population increase

- In migration

Increase in Employment

Expansion of housing

- Expansion of Towns

Growth of commercial activities

Figure 4: Indicators of Urbanisation in the Mungo Corridor (Source: Field work, 2013)

\section{Empirical Analysis of the Relationship between Agro-Industrial Development and Urbanization in the Mungo Corridor (APPENDIX I)}

There is a weak positive $\left(0.028^{\star \star}\right)$ relationship between an increase in the number of plantations and an increase in population in the Mungo Corridor at $5 \%$ level of significance. The interpretation is that, apart from an increase in the number of plantations, there are other factors which contribute to the increase in the size of the population such as the growth of commercial activities and the development of a good transport network. Still at $5 \%$ level of significance, the correlation results show that an increase in the number of plantations is positive and significantly associated with in- migration $\left(0.037^{* *}\right)$. The logical relationship is that with the increase in plantations, much labour is demanded from outside the plantation areas and this therefore precipitates in-migration in the Mungo Corridor.

At $1 \%$ significance level, it is observed that there exist a direct and significant association $\left(<0.0001^{* * *}\right)$ between the existing number of plantations and the employment level along the Mungo Corridor, that is, increasing the number of plantations raises the level of employment. This is true because with such increases, the level of either permanent or temporal employment is raised since the company demands more hands to add to the labour force either on a temporal or on a permanent basis. In addition, employment through the growth of informal sector service providers in the Mungo Corridor also increases. The expansion of housing and the number of plantations are inversely related (0.515), though this relationship is insignificant. This inverse relationship could be accounted for by the fact that it was observed that very few of the plantations operating in the Mungo Corridor have actually developed housing estates to accommodate their workers. Very few of the workers are housed in plantation dwellings while a majority is left to compete with the limited housing facilities that are meant for inhabitants who are not engaged in plantation work. In this case, the company grants the workers some little money which is described as "prime de lodgements". In addition, the results is insignificant because despite the fact that plantations have provided few housing estates, landlords have taken advantage of this situation to construct houses, no matter their qualities to give them out on rents to the population. 
The expansion of towns is indirectly and significantly $\left(0.0785^{\star}\right)$ related with the number of plantations at $10 \%$ level of significance. This implies that increasing the number of plantations reduces the town's expansion rate. Here, inference could be drawn on the phenomenon of urban constriction which operates due to the fact that most of the targeted respondents indicated that the plantations have reduced the space available for construction and expansion of their respective towns in the Mungo Corridor.

The growth of small holder plantations showed a positive and significant relationship with population increase (0.6769) and in-migration (0.531) in the Mungo Corridor. As earlier noted, an increase in the population especially due to in-migration has been very instrumental in the development of smallholder plantations as the migrant population, especially engage in their own mini-plantations. Also, a positive and significant correlation was observed for the growth of smallholder plantations and employment since the smallholder plantation owners also demand labour and consequently provide employment to the towns of the Mungo Corridor. There was also a positive correlation between the growth of smallholder plantations and housing expansion (0.7358) since the extra labour needed by the smallholdings' demand for housing thus precipitating housing expansion. In addition, a weak positive correlation (0.4938) exists between the growth of smallholder plantations and the expansion of towns in the Mungo Corridor. This could be explained by the fact that the constriction effect of smallholder schemes is not as high as those imposed by the major plantation establishments. In other words, the existence of the major plantations has limited the space for settlement expansion in the towns of the Mungo Corridor.

The growth of linked industries and population increase in the Mungo Corridor showed a positive and significant correlation $\left(0.0673^{*}\right)$ at $10 \%$ level of significance. The multiplication of service industries in the Mungo Corridor is in line with the Cumulative Causation Model and its multiplier effect which is centred on the fact that with the creation of economic activities, there is bound to be the attraction of other industries and also an increase in the population of the area in question. Surprisingly, a weak positive correlation was observed for the growth of linked industries and in-migration $\left(0.0012^{\star \star *}\right)$ and employment $\left(<0.0001^{* \star *}\right)$ at $1 \%$ level of significance. In addition, a weak positive correlation was observed for housing expansion $\left(0.0287^{\star *}\right)$ at $5 \%$ significance level and for the expansion of the towns (0.2239).

Based on the observed relationships, it is realized that most of the indicators of agro-industrial development and urbanization show a linear relationship.

\section{CONCLUSION}

Between 1960 and 2010, a more than 35\% increase in the size of plantations was registered for all plantation crops in the Mungo Corridor. The urban settlements within the Mungo Corridor owe their growth largely to the development of agro-industrial plantations. Key indicators of agro-plantation development in the Mungo Corridor include the growth of smallholder schemes, the growth of linked industries, increase in the number of plantations and the expansion of plantations. Furthermore, indicators of urbanization include population increase, in-migration housing expansion, among others. The empirical results show that most of the indicators of agro-industrial development and urbanization show a linear relationship at varying levels of significance. Given the similarity of the growth trend for settlements in the Mungo Corridor, the recommendations could be applied to redress the urban growth problems of these areas.

\section{RECOMMENDATIONS}

Based on the results of the study, the following recommendations are proposed:

For the other parts of the Mungo where plantation camps have not been constructed, the study recommends that it is necessary for these authorities to, as a short term measure augment the "prime de logements" (housing allowances) which they give to plantation workers. This is because the increasing populations of plantation workers, coupled with those of the inhabitants who are involved in other economic activities have outpaced the housing facilities in these areas, especially in Loum, Mbanga, Penja and Njombe. Such an increase in population has led to increase in the cost of housing and rents have increased about three folds. As a long term measure, there is a need to build modern plantation camps which should refurbish the existing camps created by others such as the CDC and SOCAPALM. In this connection, the authorities should budget with increasing population before constructing such houses so that they can meet up with the housing demands of the $21^{\text {st }}$ Century in terms of housing/room density, water supply and electricity as well as hygiene and sanitation.

PHP should construct living quarters for her workers so as to help suck away the pressure within the town as plantation workers and non-plantation inhabitants struggle for housing. 
Real estate operators should be closely monitored to ensure that the high rents charged for houses are checked. This situation will reduce the exploitation of the majority of the poor urbanites who either earn very meager salaries from their plantation jobs or struggle out of the plantations to eke out a living. To further check this, the municipal authorities, in collaboration with Habitat for Humanity should initiate a project to construct houses and give out at moderate rates to these urbanites.

Since a nexus was observed between the spatial distribution of plantations and the development of urban growth points, it is necessary to recommend that radical planning measures should be instituted in these areas so as to reverse the trend of urban growth problems and avoid future challenges that go with the anarchical and unplanned expansion of these plantation settlements. This should be the prerogative of the municipal authorities and the Delegation of Urban Development and Town Planning and Housing.

The public should be educated by the council on the need to properly manage their waste. Sensitization campaigns should be done using radios, television, on news papers and in schools to educate people on proper ways of handling solid waste and keeping the surrounding clean. In an addition to that the community should adopt a self -help approach to solve the problem. It is hoped that these recommendations when considered for action by the government, local authorities, and the people themselves would help to address the solid waste management problem and its related issues in the Mungo Corridor.

\section{BIBLIOGRAPHY}

Ako, A. A, Shimada, J., Kimpei, I., Katsuaki, K., Takahiro, H., Takem, G.E.E. and Iskandar, I. (2010): Hydrochemical and isotopic characteristics of water resources in the Banana Plain (Mungo Division) Cameroon. In Zuber A., Kania, J. and Kmiecik E. eds (2010): XXXVIII IAH Congress on Groundwater Quality Sustainability, Krakow, 1217 Sept 2010, Extended Abstractid: 168, University of Silesia Press 2010, Krakow, Poland.

Fombe, L. F. and Balgah, S. N. (2010): Urbanisation Process in Cameroon: Patterns, Implications and Prospects, Nova Science Publishers Inc. New York.

Fossung, E. Y. W. (2001): The Role of Plantation Agriculture in Regional Development: The Case of the Cameroon Development Corporation. In Lambi, C. M \& Eze, B. E. (eds. 2001): Readings In Geography, Unique Printers Bamenda.

GTZ (2006): Projet pour l' Amelioration de l'acces a l'eau potable et de l'assainissement de base dans les trios communes rurales de Manjo, Loum et Penja/Njombe, Province de Littoral-Cameroun. Douala-Cameroon: German Technical Cooperation.

Karush, G. E. (1978): Plantations, Population, and Poverty: The Roots of the Demographic Crisis in El Salvador. Journal of Studies in Comparative International Development (SCID) Volume 13, Number 3 /September, 1978. http://www.springerlink.com/content/j8r775527p/ Accessed on 13/03/2010.

Kimengsi. J.N. (2008): The Contribution of Pamol Plantation and Its Associated Environmental Impacts to the Development of Ekondo-Titi Sub-Division, South West Province of Cameroon. Unpublished M.Sc. Thesis, Department of Geography, University of Buea.

Kimengsi, J.N (2009): Pamol Industrial Growth and Land Use Conflicts in Ekondo-Titi Sub-Division, South West Region of Cameroon. Proceedings of the 2nd Post Graduate Seminar Organised on January 28th 2009 on Conflict Resolution, Prevention and Management by the Faculty of Social and Management Sciences, University of Buea, Cameroon.

Nasreen M., Hossain K. M. and Kundu D.K. (2006): The Interrelationship between Poverty, Environment and Sustainable Development in Bangladesh: An Overview. http://www.bangladeshsociology. org/BEJS\%203.2\%20Nasreen.pdf. Accessed 12/11/2012.

Narayanan P. and Hanjagi A. D. (2009): Land Transformation: A Threat on Bangalore's Ecology - A Challenge for Sustainable Development. Theoretical and Empirical Researches in Urban Management Special Number 1S/April 2009: Urban Issues in Asia.

Nsiah-Gyabaah (2008): Urbanization Processes - Environmental and Health effects in Africa, PERN Cyber seminar on Urban Spatial Expansion

Ogen, O. (2007): The Agricultural Sector and Nigeria's Development: Comparative Perspectives from the Brazilian Agro-Industrial Economy, 1960-1995.

Cite this Article: Fru CF and Kimengsi JN, (2015). An Empirical Analysis of the Relationship between Plantation Development and Urbanization in the Mungo Corridor of Cameroon, Nigeria. Greener Journal of Environmental Management and Public Safety, 4(1):001-008, http://doi.org/10.15580/GJEMPS.2015.1.042914209. 


\section{APPENDIX I}

Empirical Results of the relationship between agro-industrial development and urbanization in the Mungo Corridor

\begin{tabular}{|c|c|c|c|c|c|}
\hline & $\begin{array}{l}\text { Population } \\
\text { increase }\end{array}$ & In Migration & Employment & $\begin{array}{c}\text { Expansion of } \\
\text { housing }\end{array}$ & Expansion of Towns \\
\hline \multirow[t]{2}{*}{ Increase number of plantations } & 0.1073 & 0.1017 & 0.22 & -0.0318 & -0.0858 \\
\hline & $\left(0.028^{\star \star}\right)$ & $\left(0.037^{\star \star}\right)$ & $\left(<0.0001^{\star \star \star}\right)$ & $(0.515)$ & $\left(0.0785^{\star}\right)$ \\
\hline \multirow[t]{2}{*}{ Expansion of plantations } & -0.0009 & -0.0445 & -0.0376 & -0.0268 & -0.0377 \\
\hline & $(0.9845)$ & $(0.3625)$ & $(0.441)$ & $(0.5837)$ & $(0.4409)$ \\
\hline \multirow[t]{2}{*}{$\begin{array}{l}\text { Growth of small holder } \\
\text { plantations }\end{array}$} & 0.0204 & 0.0306 & 0.0298 & 0.0165 & -0.0334 \\
\hline & $(0.6769)$ & $(0.531)$ & $(0.5422)$ & $(0.7358)$ & $(0.4938)$ \\
\hline \multirow[t]{2}{*}{ Growth of linked industries } & 0.0893 & 0.1515 & 0.2309 & -0.1066 & -0.0594 \\
\hline & $\left(0.0673^{\star}\right)$ & $\left(0.0012^{\star \star *}\right)$ & $\left(<0.0001^{* \star *}\right)$ & $\left(0.0287^{\star \star}\right)$ & $(0.2239)$ \\
\hline
\end{tabular}

Probability values in parenthesis: ${ }^{\star \star \star} p<0.01,{ }^{\star \star} p<0.05,{ }^{\star} p<0.1$

(*** significant at $1 \%$, ** significant at $5 \%$ and ${ }^{*}$ significant at $10 \%$ )

Source: Computed from Questionnaire Returns with the aid of the Sata 11.1 Statistical Package 